\title{
Genetics of atrioventricular canal defects
}

\author{
Flaminia Pugnaloni ${ }^{1}$, Maria Cristina Digilio ${ }^{2}$, Carolina Putotto ${ }^{1}$, Enrica De Luca ${ }^{1}$, Bruno Marino ${ }^{1}$ and \\ Paolo Versacci ${ }^{1 *}$ (D)
}

\begin{abstract}
Atrioventricular canal defect (AVCD) represents a quite common congenital heart defect (CHD) accounting for 7.4\% of all cardiac malformations. AVCD is a very heterogeneous malformation that can occur as a phenotypical cardiac aspect in the context of different genetic syndromes but also as an isolated, non-syndromic cardiac defect. AVCD has also been described in several pedigrees suggesting a pattern of familiar recurrence. Targeted Next Generation Sequencing (NGS) techniques are proved to be a powerful tool to establish the molecular heterogeneity of AVCD. Given the complexity of cardiac embryology, it is not surprising that multiple genes deeply implicated in cardiogenesis have been described mutated in patients with AVCD. This review attempts to examine the recent advances in understanding the molecular basis of this complex CHD in the setting of genetic syndromes or in nonsyndromic patients.
\end{abstract}

Keywords: Congenital heart disease, Atrioventricular canal defect, Genetics

\section{Introduction}

The atrioventricular canal defect (AVCD), also called atrioventricular septal defect, is a quite common congenital heart defect (CHD), accounting for $7.4 \%$ of all cardiac malformations. It can be anatomically classified in complete, partial and intermediate types. Complete AVCD includes ostium primum atrial septal defect, a common atrioventricular valve and a confluent posterior ventricular septal defect located in the inlet portion of ventricular septum. Partial AVCD is characterized by ostium primun septal defect and two distinct orifices of the atrioventricular valves with cleft of the antero-medial leaflet of the mitral valve. The intermediate AVCD has a restrictive ventricular septal defect associated with anatomical characteristics of partial AVCD [1].

From an embryological point of view, AVCD was traditionally considered caused by a primary intracardiac mechanism consisting in the maldevelopment of atrioventricular endocardial cushions in relation to defects of

\footnotetext{
* Correspondence: paolo.versacci@uniroma1.it

'Department of Pediatrics, Obstetrics and Gynecology, "Sapienza" University of Rome, Policlinico Umberto I, Viale Regina Elena, 324, 00161 Rome, Italy Full list of author information is available at the end of the article
}

extracellular matrix, leading to absent or incomplete fusion of ventral (antero-superior) and dorsal (postero-inferior) atrioventricular cushions [2-4]. Nevertheless, the hypothesis that extracardiac progenitor cells contribute also to the growth of the inlet part of the heart has been postulated following the experimental studies in chick embryos performed by Maria Victoria de la Cruz from 1977 on. In fact, later studies have confirmed that a population of extramesenchymal cells known as spina vestibuli or dorsal mesenchymal protrusion (DMP), arising from the posterior segment of the secondary heart field (SHF) in the splanchnic mesoderm, grow towards the atrial surface of the primitive atrioventricular canal, in particular towards the inferior dorsal endocardial cushion, to close the primary atrial foramen and form the atrioventricular junction [5-9].

The AVCD is associated with extracardiac defects in about $75 \%$ of the cases and presents strong genetic association [10-13]. The best known genetic syndrome associated with AVCD is Down syndrome (DS) (45\% of the cases) [10-13]. Other chromosomal or monogenic syndromes are accounting for about $15 \%$ of the cases [13]. Moreover, AVCD is associated with heterotaxy in

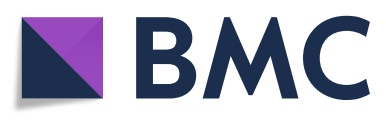

(c) The Author(s). 2020 Open Access This article is licensed under a Creative Commons Attribution 4.0 International License, which permits use, sharing, adaptation, distribution and reproduction in any medium or format, as long as you give appropriate credit to the original author(s) and the source, provide a link to the Creative Commons licence, and indicate if changes were made. The images or other third party material in this article are included in the article's Creative Commons licence, unless indicated otherwise in a credit line to the material. If material is not included in the article's Creative Commons licence and your intended use is not permitted by statutory regulation or exceeds the permitted use, you will need to obtain permission directly from the copyright holder. To view a copy of this licence, visit http://creativecommons.org/licenses/by/4.0/. The Creative Commons Public Domain Dedication waiver (http://creativecommons.org/publicdomain/zero/1.0/) applies to the data made available in this article, unless otherwise stated in a credit line to the data. 


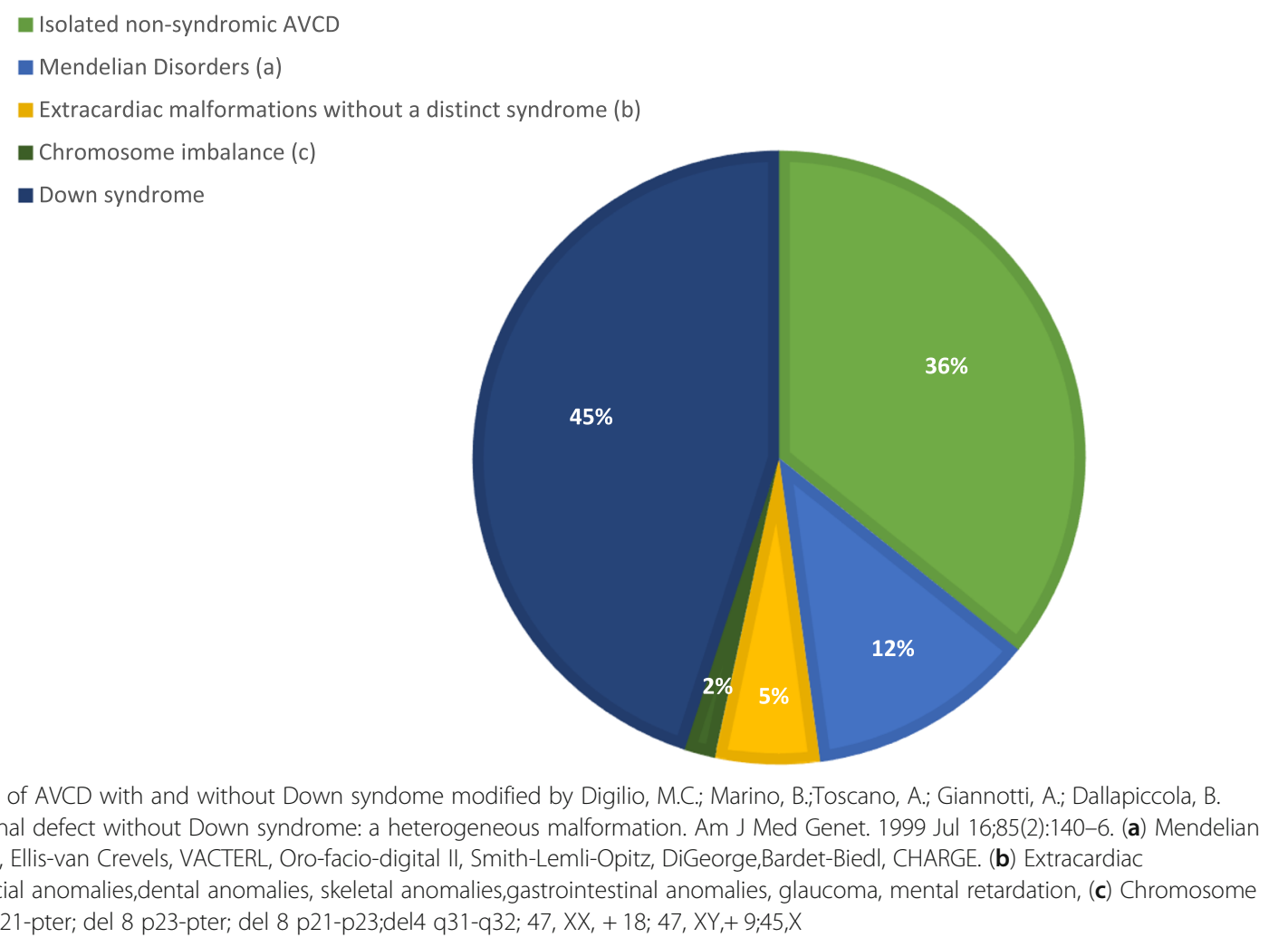

additional $15 \%$ of the cases. Isolated, non-syndromic AVCD accounts for a percentage of about $36 \%$. It is notable that among non-syndromic cases, a percentage of about $3.5 \%$ show a familial pattern of recurrence (Fig. 1).

It is noteworthy that AVCD displays anatomic variability possibly related to different and distinct genetic causes. Nevertheless, a common point seems to be causally implicated in several disorders linked to AVCD. In fact, clinical and molecular studies have demonstrated that several disease genes implicated in syndromes with AVCD encode proteins that participate in ciliary function. This was in agreement with previously known observation that dysfunction of the nodal cilium can result in left-right axis defects in vertebrates $[14,15]$. Dysfunction in cilia can lead to several human genetic disorders with overlapping phenotypes, the so called "ciliopathies" [16, 17]. The ciliary membranes harbor receptors for crucial signaling cascades, including Hedgehog signaling [18, 19]. A link between AVCD and cilia abnormalities through a specific pathogenetic pathway involving Hedgehog signaling has been recognized in several syndromes with AVCD [20-23].

\section{Syndromic AVCD and chromosomal anomalies}

Down syndrome is the most frequent genetic condition associated with AVCD. CHDs are diagnosed in 40-50\% of these patients [24]. In this syndrome AVCD is frequently complete, showing a "simple type", since rarely associated with other cardiac anomalies, with the exception of tetralogy of Fallot $[25,26]$. In particular, leftsided obstructions are significantly more rare in patients with DS and AVCD in comparison with patients with AVCD and normal chromosomes [11, 24, 27]. Clinical studies on surgical prognosis of AVCD have shown that corrective surgery in patients with DS results in lower mortality and morbidity rates, compared to the children without trisomy 21 [28, 29].

From the molecular point of view, several genes located in the "CHD critical region" on chromosome 21 have been long investigated as a cause of AVCD, including DSCAM, COL6A1, COL6A2, and DSCR1 [30,31]. Additional genes mapping on different chromosomes including CRELD1, FBLN2, FRZB, and GATA5 have been studied [32]. Particularly, the interaction between trisomic genes and modifiers on different chromosomes has been supported in experimental studies using mouse models of DS with high prevalence of CHD, in which loss-of-function alleles of Creld 1 or Hey 2 genes have been crossed with the trisomic background [33]. In addition, mouse models have evidenced the involvement of the Shh signaling pathway also in DS, since it has demonstrated that cerebral, skin, liver and intestine mice trisomic cells have a defective mitogenic Shh activity with cell proliferation impairment due to a higher expression of Ptch1, a receptor normally repressing the Shh pathway, located on Cr9 [34]. 


\section{Deletion 8p23}

Deletion of the terminal part of the short arm of chromosome 8 (del 8p23) is the second chromosomal anomaly associated with AVCD [13]. Cardiac malformations are diagnosed in two third of the patients and AVCD is detected in about $40 \%$ of the cases [35]. AVCD is generally complete, with a frequent association with pulmonary valve stenosis and Tetralogy of Fallot [36, 37]. Heart defects as dextrocardia, abnormalities of the pulmonary and systemic venous returns, common atrium, single ventricle and transposition of the great arteries are also found in a group of patients with del 8p23 [35]. Some of these malformations are also characteristic of laterality defects. The candidate gene for CHD in this syndrome is GATA4, which maps to the $8 \mathrm{p} 23.1$ region and is expressed in the developing heart [38]. GATA4 interacts with other transcriptional factors to drive DMP progression via SHH signaling [39].

\section{Deletion 3p25}

Deletion 3p25 syndrome is also often associated with AVCD [40-42]. Cardiac malformations are diagnosed in about one-third of patients with deletion 3p25 patients [42]. In this syndrome AVCD is usually complete and CRELD1 gene is the "critical "gene, based on its map position on chromosome $3 \mathrm{p} 25$ and considering that it is known to be causally related also to non-syndromic AVCD [43, 44]. The study of Burnicka-Turek et al. suggested that CRELD1 mutations can cause AVCD acting on SHF Hh signalling [45].

\section{Syndromic AVCD and monogenic disorders Ciliopathies}

Several syndromes with AVCD are known to be pathogenetically related to ciliary dysfunction. This is not surprising considering that DMP development requires cilia-based Shh signaling. In fact, the role of Hedgehog signaling in coordinating multiple aspects of left-right lateralization and cardiovascular growth is well known. In addition, Sonic Hedgehog knock-out mice show CHDs in the setting of heterotaxy and left pulmonary isomerism [46-48].

Ciliopathies with AVCD can be divided in syndromes with polydactyly and syndromes without polydactyly. Among syndromes with polydactyly, ciliary dysfunction through abnormal processing of the Hh proteins has been documented in Ellis-van Creveld and other shortrib polydactyly, Smith-Lemli-Opitz, and oral-facialdigital type IV syndromes [22, 23, 49] while ciliary function is directly involved in Bardet-Biedl, oral-facialdigital I and VI syndromes [20, 21, 50, 51].

Syndromes with ciliary involvement and AVCD without polydactyly include VACTERL association and Alveolar Capillary Dysplasia.
AVCD in the context of these syndromes shows anatomical similarities with cardiac malformations found in heterotaxy and polysplenia $[3,52]$.

\section{* Ellis-van Creveld syndrome}

The Ellis-van Creveld syndrome is an autosomal recessive disorder characterized by short-limb dwarfism, short ribs, postaxial polydactyly of hands and feet, ectodermal defects and CHD [53]. Cardiac malformations are diagnosed in about two thirds of affected patients, prevalently AVCD associated with common atrium and systemic and pulmonary venous abnormalities $[13,52$, 54]. Interestingly, AVCD is rarely associated with common atrium in the non-syndromic patients, but frequently associated in heterotaxy [55]. In the majority of the cases, Ellis-van Creveld syndrome is due to mutations in $E V C$ and $E V C 2$ genes but mutations in WDR35 and DYNC2LI1 gene have been demonstrated in single patients. $E V C$ and $E V C 2$ genes are required for normal transcriptional activation of Indian Hedgehog signalling [22, 53], with involvement of the proximal end of the primary cilium function [56]. The WDR35 encodes a retrograde intraflagellar transport (IFT) protein that is required for the recruitment of the EVC-EVC2-SMOH complex to the cilium [57]. The DYNC2LI1 gene codes for a component of the intraflaggelar transport-related dynein-2 complex, required for cilium assembly and function $[58,59]$.

\section{* Oral-facial-digital syndromes}

The oral-facial-digital syndromes include a group of 18 clinical subtypes with overlapping clinical features, including malformations of the face, oral cavity, and digits (polysyndactyly) [60]. CHD can also been present, and AVCD has been frequently diagnosed in patients with OFD syndrome type II [61] and type VI [62] and common atrium in OFD syndrome type I [63].

Several genes related to ciliary function and/or Sonic Hedgeghog signalling have been identified, as the $\mathrm{X}$ linked dominant OFD1 gene, encoding for a centrosomal protein involved in ciliary function [64], the WDPCP gene linked to the planar cell polarity ciliogenesis [65] and the TCTN3 gene implicated in transduction of Sonic Hedgehog signalling [49].

\section{* Joubert syndrome}

Joubert syndrome is a group of genetically heterogeneous conditions characterized by multiorgan involvement (retinal, renal, hepatic and skeletal) and the pathognomonic neuroradiological "molar tooth sign". Joubert syndromes can be associated with CHDs, including left ventricular obstructions, alone or associated with AVCD [52, 66]. Joubert syndromes are classified among 
ciliopathies, and more than 30 causative genes have been reported by now [67].

\section{* Bardet-Biedl syndromes}

Bardet-Biedl syndrome is an autosomal recessive disorder characterized by obesity, retinitis pigmentosa, postaxial polydactyly, genitourinary malformations, cognitive impairment, and CHD [68]. Laterality defects are described, including AVCD, dextrocardia without structural cardiac defects and abdominal situs inversus [23, 69, 70]. The AVCD can be considered the "classic" CHD in this syndrome. The syndrome is genetically heterogeneous, with several genes implicated, whose proteins are involved in ciliary function regulation [20].

\section{* Smith-Lemli-Opitz syndrome}

Smith-Lemli-Opitz syndrome (SLOS) is an autosomal recessive syndrome characterized by developmental delay, growth retardation, cleft palate, CHD, hypospadia, toe syndactyly, postaxial polydactyly, and facial anomalies [71]. CHD occurs in one-half of patients with SLOS [72]. Septal defects and AVCD are the most common CHDs and AVCD is often associated with anomalous pulmonary venous return, the latter being also a cardiac manifestation of heterotaxy with asplenia [72].

SLOS is due to an inborn error of cholesterol metabolism with deficiency of the 7-dehydrocholesterol-7 reductase (DHCR7) activity, due to mutations in the DHCR7 gene. Cholesterol plays a critical role in formation of the normally active hedgehog proteins. Abnormal processing of Hedgehog proteins secondary to abnormal cholesterol levels seems to have a role in the development of SLO syndrome malformations [73].

\section{* VACTERL association}

VACTERL is a non-random association of congenital anomalies. Main clinical features are including vertebral defects (V), anal atresia (A), esophageal atresia (TE), radial and renal dysplasia (R) and limb anomalies (L), but CHDs are also an important finding in $50-80 \%$ of patients. Anatomic types of CHDs include septal, conotruncal and laterality defects (dextrocardia, heterotaxy, AVCD and transposition of the great arteries) [74].

The causal mechanisms underlying VACTERL association are heterogeneous and not completely established. Clinical observations and molecular studies in mice are showing that the association could be caused by defective $\mathrm{SHH}$ signaling and ciliopathies could be involved [75-77]. Genes described to cause the spectrum of malformations of VACTERL association include Ift42 [78], FOXF1 [77] and ZIC3 [76, 77].

\section{Alveolar capillary dysplasia}

Alveolar capillary dysplasia is a congenital pulmonary vascular abnormality, often associated with misalignment of the pulmonary vessels. The disease is associated with CHD in about $10 \%$ of the cases, prevalently consisting in partial or complete AVCD and various degrees of left heart obstruction (small left ventricle with or without aortic coarctation) [79].

Alveolar capillary dysplasia is caused by FOXF1 gene mutations. Several studies demonstrated that FOXF1 gene is activated by Sonic Hedgehog signaling [80].

\section{RASopathies}

The term RASopathies includes the Noonan Syndrome and similar related syndromes (i.e., the LEOPARD syndrome or "Noonan syndrome with Multiple Lentigines", the cardio-facio-cutaneous syndrome, the Costello syndrome, the Mazzanti syndrome and others) caused by mutations in genes encoding proteins with a role in the RAS/MAP kinase (MAPK) signalling pathway [81, 82].

The RASopathies are characterized by distinctive facial features, growth retardation, CHD, skeletal anomalies and variable neuropsychological deficits [81]. CHD occurs in about $65-85 \%$ of cases, depending on the mutated genes. Although pulmonary valve stenosis with dysplastic leaflets and hypertrophic cardiomyopathy of left ventricle are the most frequent cardiac defects, AVCD was also described. PTPN11 and RAF1 gene mutations have been prevalently detected in patients with AVCD associated with RASopathies [83-85]. AVCD is usually partial and may be associated with systemic obstructions including subaortic stenosis or aortic coarctation [85]. Structural abnormalities causing congenital subaortic stenosis include accessory fibrous tissue and/ or anomalous insertion of mitral valve and anomalous papillary muscle of left ventricle [83-85].

Normal SHP2/PTPN11 function seems to act as IHH suppressor, and experiments in mice have documented decreased IHH levels in Noonan syndrome caused by germline activating mutations in PTPN11 [86].

\section{CHARGE syndrome}

CHARGE syndrome is characterized by ocular coloboma, choanal atresia, growth and developmental delay, genital anomalies and hearing loss. CHD is detectable in about $85 \%$ of patients with CHARGE syndrome [87] and AVCD is the second most frequent cardiac malformation, often in association with tetralogy of Fallot $[88,89]$.

The syndrome is caused by mutations in the CHD7 gene in the majority of the patients [90].

\section{Holoprosencephaly}

CHDs including septal defects have been described also in patients with holoprosencephaly [91]. Holoprosencephaly 
(HPE) is a severe congenital forebrain disorder usually associated with a broad spectrum of facial anomalies ranging from single axillary dental incisor and hypotelorism to extreme features such as cyclopia, proboscis and cleft lip with or without cleft palate. Shh role on commitment of the midline of neural structures is well known. Until now, at least $10 \mathrm{HPE}$ loci have been identified (Shh [92, 93], DKK1 [94],GLI [95], SIX3 [96], PTCH1 [97], TDGF1 [98], TGIF [99] and ZIC2 [100]). All the genes previously mentioned functionally interact or regulate the Shh concentration to drive forebrain development and ventral midline cell induction during different embryonic stages. In fact, the Shh $-/-$ (null) mouse embryo displays a severe form of HPE [46, 92, 93, 101]. A correct regulation of Shh concentration is therefore crucial for the correct brain septation. However, Shh signaling pathway is deeply implicated also in ciliary function and acts on the DMP to drive the proper development of the cardiac AVC. In fact, in human beings, Shh pathway dysregulation has a well known impact on different types of AVCD [23]. This molecular considerations are supported by the striking phenotypical similarities between sonogram images of HPE (due to SHH deficiency in brain development) (Fig. 2a) and echocardiographic images of AVCD (Fig. 2b). Images (and phenotypes), indeed, support the unifying role of Sonic Hedgehog signalling on the commitment of midline structures of both brain and heart.

\section{Ethnic variations}

In different ethic population AVCD can show distinct prevalence also in the context of the same syndrome supporting the multiple genetic origin of this CHD. In particular, in the context of DS, several studies highlight the effect of sex and ethnic factors in addition to trisomy 21 to determine different prevalence of AVCD.

It is notable that in oriental and native-American DS patients the most frequent CHD is represented by VSD whereas in Caucasian DS populations AVCD are prevalent [102-104]. Freeman et al. reported significant ethnic differences in the prevalence of AVCD in DS patients. The study demonstrated that blacks with DS were twice as likely to be born with a complete AVCD whereas Hispanics DS patients showed a trend toward fewer AVCD [105].

\section{Non-syndromic atrioventricular canal defects}

The majority of AVCD not related to trisomy 21 occur as sporadic cases [13] and non-syndromic patients with visceroatrial situs solitus (without heterotaxy) account for about 25\% [13]. Indeed, AVCD prevalence decreases to $0.97-1.32$ per 10,000 livebirths looking at nonsyndromic cases (Fig. 1). In this population of nonsyndromic patients, only $3-5 \%$ show familial recurrence. The autosomal dominant pattern of inheritance is prevalently involved, sometimes with incomplete penetrance. There is emerging evidence that maternal risk factors (genetic and environmental) can confer a major risk for non-syndromic CHD [106, 107].

The first gene mapped for AVCD was CRELD1, located inside the "CHD critical region" on 3p25, known as the AVCD2 locus. CRELD1 gene acts as a regulator of calcineurin/NFATc1 signaling which is crucial for the regulation of cardiac development. In fact, NFATc signaling determines valve initiation and maturation, regulating the activity of VEGF to undergo endomesenchimal transition (EndoMT) [108]. CRELD1 the most frequently AVCD associated gene, since heterozygous mutations have been shown to occur in about $6 \%$ of non-syndromic partial AVCD [109]. In addition, some CRELD1 gene mutations, including the c.985C $>\mathrm{T}$ (p.Arg329Cys) as recurrent one [110], have been reported to be a risk factor for CHD also in patients with DS [111]. Experimental studies in mice have shown that the introduction of a null allele of Creld1 in theDs65Dn mouse can increase the prevalence of CHDs [112]. Interestingly, a
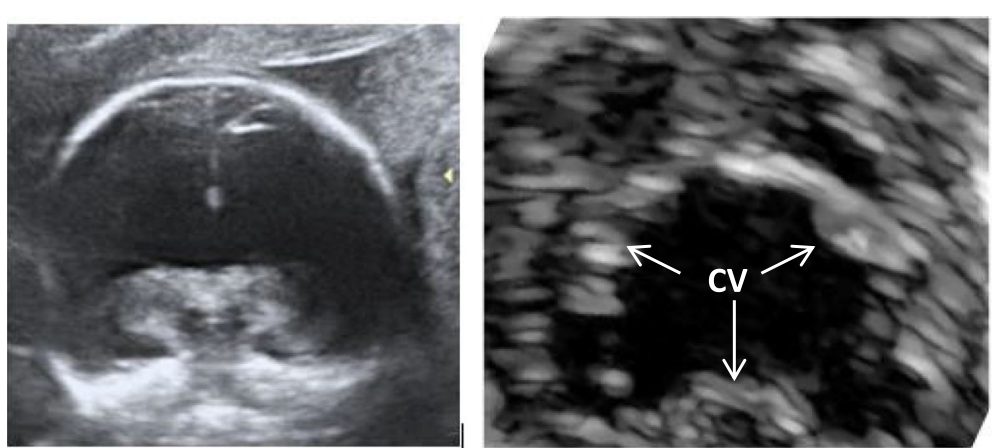

Fig. 2 a Coronal sonogram of fetal head with alobar holoprosencephaly. b Echocardiographic subcostal view of common atrioventricular valve in the context of complete AVCD. CV: common valve 
link between CRELD1 and ciliary dysfunction through disruption of Shh signaling has been suspected [45, 113].

The fact that defective NFATC1 function could contribute to isolated AVCD was also demonstrated by a recent work by Ferese et al. [114]. The authors reported missense rare variants in NFATC1 gene in two patients with non-syndromic AVCD and in one syndromic patient with AVCD in the context of heterotaxia and polysplenia with left isomerism. Experimental studies in zebrafish have demonstrated that NFATC1 variants have a great impact on cardiogenesis, affecting specifically cardiac looping process. Interestingly, a link between NFATC1 and CRELD1 genes has been noted, since CRELD1 has been shown to be a master regulator of calcineurin/NFATC1 signaling [114].

Several studies highlight the importance of testing "syndromic" genes when investigating patients with isolated CHDs. Some genes causative or contributory for specific syndromes with cardiac involvement can play a role also in isolated AVCD. In fact, linkage studies of familial AVCD first excluded chromosome 21 loci in the pathogenesis of isolated sporadic AVCD [115, 116].

Weissman et al. [117] reported a non-synonymous mutation of PTPN11 in a subject with isolated complete AVCD. Missense mutation of this gene account for approximately $50 \%$ of Noonan syndrome, an autosomal dominant disorder presenting with atrioventricular septal defects in almost $15 \%$ of cases.

Recently, D'Alessandro et al. [118] performed a NGS (exome sequencing) analysis in a large cohort of unrelated AVCD probands and in a replication cohort of unrelated, non-syndromic, Caucasian AVCD probands. Data for replication analysis were obtained from population databases. The authors found rare damaging non-synonymous variants in six genes (NIPBL, CHD7, CEP152, BMPR1a, ZFPM2, MDM4) all known for their association with some syndromes with CHDs. In humans there is a considerable phenotypic heterogeneity in AVCD whereby different genes can contribute to the same phenotype. For these reasons, NGS is a powerful tool that has the potential to increase the specificity and accuracy of the observed results.

One of the most robustly CHD-associated gene is GATA4, mapping on the "CHD critical region" 8p23.1 [38]. GATA4 is a developmental transcription factor associated with atrial septal defects and ventricular septal defects but also with non-syndromic AVCD.

GATA4 is required for proliferation of SHF atrial septum progenitors and for the progression of the DMP via Hedgehog signaling. The role of GATA4 in cardiac AVC septation is therefore deeply dependent on Shh signaling [39].
Thanks to the wide spread of NGS techniques additional locus for isolated AVCD have been found. Rare de novo missense variants in NR2F2 were described by $\mathrm{Al}$ Turky et al. in 13 trios and 112 unrelated individuals with non-syndromic AVCD [119]. The role of NR2F2 gene on cardiogenesis was postulated on the basis of a previously published mutant mouse that shows defective endothelial mesenchymal transformation and hypocellularity of the atrioventricular canal, strongly suggesting a role for NR2F2 in cardiac developmental in a dosagesensitive fashion [120].

Priest et al. in a recent study confirmed that de novo mutations may account for a small fraction of isolated CHDs [121]. The authors found rare de novo variants in multiple genes (NR1D2, ADAM17, RYR1, CHRD, PTPRJ, IFT140, ATE1, NOTCH1, NSD1, ZFPM2, MYH6, VCAN, SRCAP, KMT2D, NOTCH2, BBS2, EHMT1) surveying a multi-institutional cohort, combining analysis of 987 individuals (discovery cohort of 59 affected trios and 59 control trios, and a replication cohort of 100 affected singletons and 533 unaffected singletons). The study was ruled out combining both exomesequencing and array-CGH, suggesting a locus heterogeneity and a oligogenic inheritance of isolated AVCD.

The possible role of genomic structural variants such as copy number variants (CNV) in the etiology of nonsyndromic AVCD has only been studied in a minority of cases. Priest et al. [122] identified two sub-chromosomal deletions occurring in cr20p12.3 and in cr3q26.1 respectively, previously not directly linked to AVCD. However, the deletions found at these loci contain some genes that can be linked to cardiac morphogenesis. The authors, indeed, conclude that large CNV might confer a minor risk for isolated AVCD.

The studies cited above indicate that isolated nonsyndromic AVCD is a highly genetically heterogeneous malformation that probably requires an unknown combination of factors to break the theoretical disease threshold. Noteworthy, specific genes implicated in different steps of cardiogenesis can have a contributory role in different CHD. This observation provides additional evidence of the wide molecular heterogeneity in establishing cardiac phenotype and highlights the fact that CHDs are not to be considered monogenic disorders.

\section{Familial AVCD}

The Baltimore Washington Infants Study revealed that among non-syndromic children showing CHDs, only 3$5 \%$ presented familial recurrence. Studies on several pedigrees showed that the recurrence risk for CHD among siblings of patients with AVCD was about 3.6\% [123], similarly to the mean recurrence risk reported in previous studies [124]. 
Traditionally, segregation analysis in families with AVCD suggested an autosomal dominant pattern of inheritance related to a major gene. The hypothesis that AVCD shared a monogenic or oligogenic pattern of inheritance agreed with the clinical observation that CHDs in the offsprings were concordant with cardiac defects in parents [123]. Nevertheless, recent studies on large pedigrees highlight low concordance ratios in families and importance of sex and ethnical drive as risk factor for recurrence rates. These observations support the multigenic origin of familial AVCD that often shows complex traits of inheritance with incomplete penetrance $[125,126]$.

Molecular basis of familial AVCD are largely unknown. Due to the fact that AVCD represent the major CHD among DS patients, candidate genes on chromosome 21 were firstly investigated with linkage analysis studies. The results, however, excluded the involvement of chromosome 21 "critical region" loci $[115,116,127]$. Exclusion of linkage with chromosome 21 in families with recurrence of nonsyndromic AVCD was also consistent with previous observations on anatomic differences between Down and non-Down AVCD [13].

Some genes deeply implicated in cardiogenesis have been found in pedigrees with AVCD. Missense mutation in CRELD1 gene, mapping on cr3p, has been described in the context of familial AVCD [128, 129] as well as mutations in PTPN11 [117],GATA4 [130] and the $p 93$ gene, mapping on chromosome $1 \mathrm{p}$ [131].

A recent work of Demal et al. reported a family with multiple cardiac defects including AVCD and found out that every affected family member carries a BMPR1A missense mutation. BMPR1A is required to ensure the correct development of endocardial cushions via EndoMT regulating the $\mathrm{Wnt} / \mathrm{B}$-catenin signalling. The reported BMPR1A variant leads to reduced atrioventricular valve area and ectopic valvular tissue in experimental studies in zebrafish and is to be considered a potential candidate gene in the development of nonsyndromic AVCD [132].

Familial and isolated cases of AVCD sometimes show variants in genes encoding for transcriptional factors deeply implicated in cardiogenesis such as TBX20 and $T b \times 2 . T b x 20$ is a T-box transcription factor that interacts with $T b x 2$ to promote EndoMT and proliferation of the AVC tissue. Therefore this gene directly acts on endocardial cushion formation [133].

Mutations in well known genes account only for a small percentage of familial AVCD, whereas the majority of isolated AVCD with familial recurrence seems to have a complex etiology based on a variety of genes. Combination of traditional linkage analysis techniques with genome and exome sequencing represent a powerful tool to evaluate complex trait of recurrence of this CHDs.

A better understanding of the molecular basis of familial AVCD could have a significant impact on clinical outcome driving a correct genetic counseling based on a focused family history.

\section{Implications for clinical practice}

The knowledge of genetic basis of AVCD can be useful for prenatal and postnatal clinical management of affected patients.

Information about the prevalence and type of genetic syndromes possibly associated with AVCD can be useful for clinicians involved in prenatal controls and for targeted screening for extracardiac defects. The link between anatomic types of AVCD and specific genetic syndrome could be a marker in diagnostic work. The large genetic heterogeneity of AVCD associated with the possible limits of prenatal genetic testing should be known in prenatal counseling.

In postnatal management of syndromic patients with AVCD it is important to try to perform an early and precise genetic diagnosis. This can lead to knowledge of risk factors, early monitoring and treatment of extracardiac defects, the use of specific multidisciplinary protocols and guidelines.

Genetic counseling to families is also important. Molecular diagnosis in the proband gives the possibility to test the parents and other relatives, in order to precise the possible familial genetic risk. Based on the present genetic knowledge, the molecular approach is more suitable for syndromic rather than nonsyndromic AVCD.

\section{Conclusions}

AVCD is a very heterogeneous cardiac phenotype that frequently occurs in association with several genetic syndromes. A better understanding of AVCD molecular background could have relevance in different clinical settings. As cited above, AVCD knowledge could drive proper genetic counselling increasing clinical usefulness of fast and high resolution tools for prenatal diagnosis such as array-CGH platforms (Fig. 3). Anatomic differences in AVCD can be caused by distinct genetic diseases. Nevertheless, molecular studies are demonstrating that several genes responsible for syndromes with AVCD can be involved in ciliary function and/or abnormal processing of proteins implicated in Hedgehog signaling. Anomalies in different components of the Hedgehog pathway can express in syndromic AVCD associated with partially overlapping clinical extracardiac manifestations.

Several studies indicate a complex genetic trait involved in non-syndromic ACVD and highlight that the 


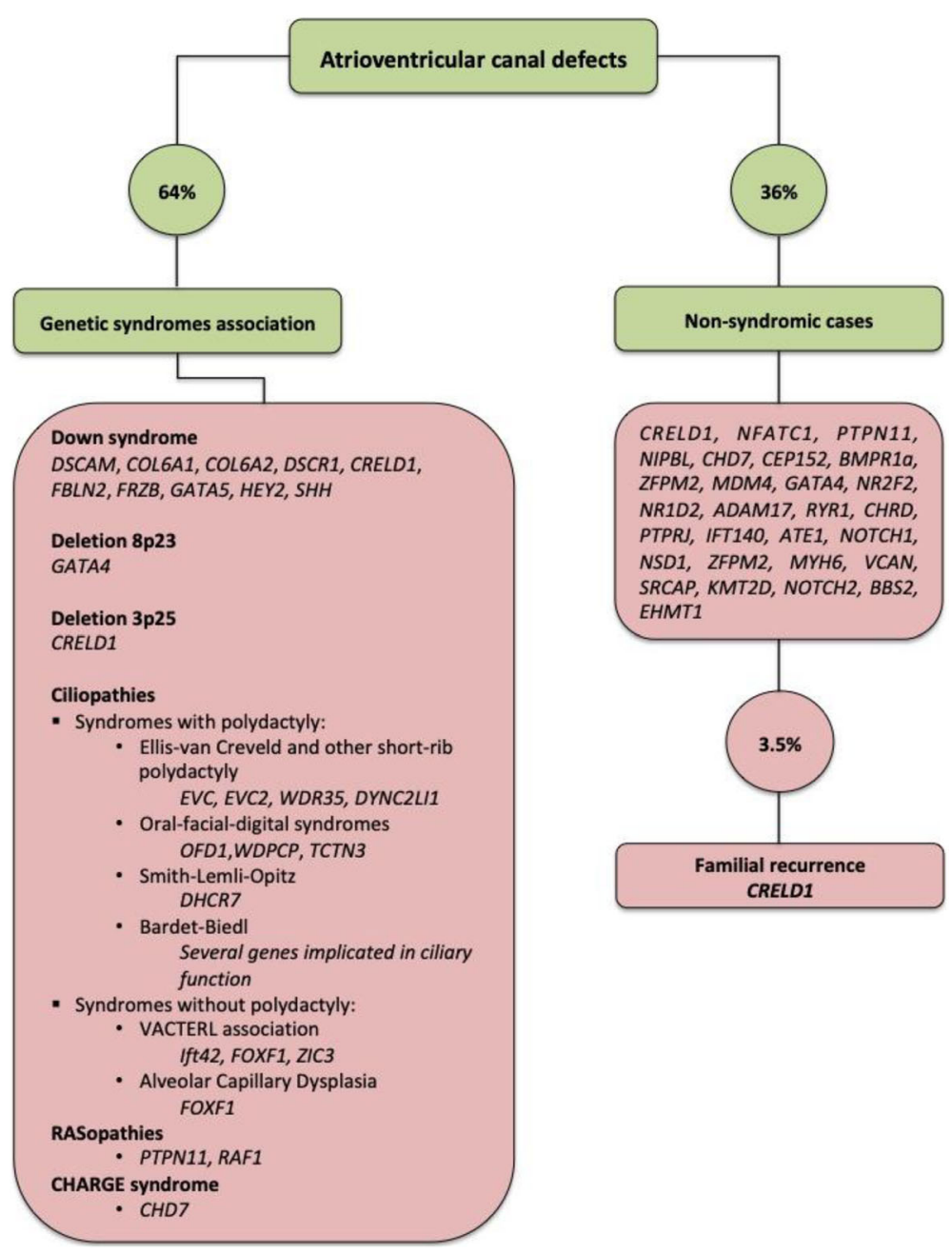

Fig. 3 Genes involved in different forms of atrioventricular canal defects

physiopathology of isolated AVCD depends on multiple molecular mechanisms.

During early cardiogenesis the correct specification of the atrial and ventricular chambers relies on two equally important embryogenetic processes. On one hand the primary intracardiac mechanism driven by the maturation of endocardial cushions via EndoMT and, on the other hand, the extracardiac mechanisms led by activation of DMP via Shh signalling to complete the AVC septation [23].

Although the pathogenesis of syndromic AVCD seems to be deeply related to DMP development driven by Shh signaling, probably in isolated non-syndromic AVCD the primary embryological step of endocardial cushion tissue proliferation following EndoMT should be still considered as an important pathogenetic mechanism.

The pathogenesis of both syndromic and isolated AVCD, however, appears to be as complex as still not completely understood. Targeted NGS offers a great opportunity to improve sensibility and specifity of genetic analysis for AVCD.

Similarly to conotruncal heart defects in the context of 22q11.2 deletion syndrome and branchial arch anomalies, AVCD can be considered as a phenotypic marker linking all syndromes related to cilia through Shh pathway. Hence, we postulate that AVCD should be considered as part of "developmental field" as introduced by Opitz et al. [134, 135].

\section{Abbreviations}

AVCD: Atrioventricular canal defect; CHD: Congenital heart defect; NGS: Next Generation Sequencing; DS: Down syndrome; DMP: Dorsal mesenchymal protrusion; SHF: Secondary heart field; IFT: Intraflagellar transport:

SLOS: Smith-Lemli-Opitz syndrome; HPE: Holoprosencephaly; SHH: Sonic Hedgehog; EndoMT: Endomesenchimal transition; CNV: Copy number variants

Acknowledgements Not applicable. 


\section{Authors' contributions}

FP designed the work, collected patient data and wrote the first draft of the paper; MCD collected patient data and wrote the first draft of the paper; $C P$ collected patient data ad contributed to interpretation of data; EDL collected patient data and contributed to the interpretation of data; BM has designed the study and revised the first draft of the paper; PV collected patient data and revised the paper. All authors read and approved the final manuscript.

\section{Funding}

No funding was granted for this research.

\section{Availability of data and materials}

The data that support the findings of this study are available from the corresponding author upon reasonable request.

\section{Ethics approval and consent to participate}

Not applicable.

\section{Consent for publication}

Not applicable.

\section{Competing interests}

The authors declare that they have no competing interests.

\section{Author details}

'Department of Pediatrics, Obstetrics and Gynecology, "Sapienza" University of Rome, Policlinico Umberto I, Viale Regina Elena, 324, 00161 Rome, Italy. ${ }^{2}$ Medical Genetics Unit, Bambino Gesù Children's Hospital and Research Institute, 00165 Rome, Italy.

Received: 11 March 2020 Accepted: 3 May 2020

Published online: 13 May 2020

\section{References}

1. Praagh V. Common atrioventricular canal with and without conotruncal malformations : an anatomic study of 251 postmortem cases. Congenit Heart Dis. 1984:599-639.

2. Clark EB. Mechanisms in the pathogenesis of congenital heart defects. In: Pierpont ME, Moller J, editors. The Genetics of Cardiovascular Disease. Boston: Martinus-Nijoff; 1986. p. 3-11.

3. Clark EB. Pathogenetic mechanisms of congenital cardiovascular malformations revisited. Semin Perinatol. 1996;20(6):465-72. https://doi.org/ 10.1016/S0146-0005(96)80062-0.

4. Pierpont ME, Markwald RR, Lin AE. Genetic aspects of atrioventricular septal defects. Am J Med Genet. 2000;97(4):289-96. https://doi.org/10.1002/10968628(200024)97:4<289::AID-AJMG1279>3.0.CO;2-U.

5. Lamers WH, Moorman AFM. Cardiac septation: a late contribution of the embryonic primary myocardium to heart morphogenesis. Circ Res. 2002; 91(2):93-103. https://doi.org/10.1161/01.RES.0000027135.63141.89.

6. Blom NA, Ottenkamp J, Wenink AGC, Gittenberger-de Groot AC. Deficiency of the vestibular spine in atrioventricular septal defects in human fetuses with Down syndrome. Am J Cardiol. 2003;91(2):180-4. https://doi.org/10. 1016/S0002-9149(02)03106-5.

7. Gittenberger-de Groot AC, Calkoen EE, Poelmann RE, Bartelings MM, Jongbloed MRM. Morphogenesis and molecular considerations on congenital cardiac septal defects. Ann Med. 2014;46(8):640-52. https://doi. org/10.3109/07853890.2014.959557.

8. Snarr BS, Wirrig EE, Phelps AL, Trusk TC, Wessels A. A spatiotemporal evaluation of the contribution of the dorsal mesenchymal protrusion to cardiac development. Dev Dyn. 2007;236(5):1287-94. https://doi.org/10. 1002/dvdy.21074.

9. Briggs LE, Kakarla J, Wessels A. The pathogenesis of atrial and atrioventricular septal defects with special emphasis on the role of the dorsal mesenchymal protrusion. Differentiation. 2012;84(1):117-30. https:// doi.org/10.1016/j.diff.2012.05.006.

10. Rowe RD. Cardiac malformation in mongolism. Am Heart J. 1962;64(4):5679. https://doi.org/10.1016/0002-8703(62)90043-1.

11. Marino B. Atrioventricular septal defect-anatomic characteristics in patients with and without Down's syndrome. Cardiol Young. 1992;2(4):308-10. https://doi.org/10.1017/\$1047951100007861.
12. Ferencz C. Genetic and environmental risk factors of major cardiovascular malformations : the Baltimore-Washington infant study 1981-1989. Perspect Pediatric Cardiol. 1997;5:346-7.

13. Digilio MC, Marino B, Toscano A, Giannotti A, Dallapiccola B. Atrioventricular canal defect without Down syndrome: a heterogeneous malformation. Am Jed Genet. 1999;85(2):140-6. https://doi.org/10.1002/(SICI)10968628(19990716)85:2<140::AID-AJMG8>3.0.CO;2-A.

14. Supp DM, Witte DP, Potter SS, Brueckner M. Mutation of an axonemal dynein affects left-right asymmetry in inversus viscerum mice. Nature. 1997; 389(6654):963-6.

15. Okada Y, Nonaka S, Tanaka Y, Saijoh Y, Hamada H, Hirokawa N. Abnormal nodal flow precedes situs inversus in iv and inv mice. Mol Cell. 1999;4(4): 459-68. https://doi.org/10.1016/S1097-2765(00)80197-5.

16. Tobin JL, Beales PL. The nonmotile ciliopathies. Genet Med. 2009;11(6):386402. https://doi.org/10.1097/GIM.0b013e3181a02882.

17. Waters AM, Beales PL. Ciliopathies: an expanding disease spectrum. Pediatr Nephrol. 2011;26(7):1039-56. https://doi.org/10.1007/s00467-010-1731-7.

18. Huangfu D, Liu A, Rakeman AS, Murcia NS, Niswander L, Anderson KV. Hedgehog signalling in the mouse requires intraflagellar transport proteins. Nature. 2003;426(6962):83-7. https://doi.org/10.1038/nature02061.

19. Anderson KV. Cilia and hedgehog signaling in the mouse embryo. Harvey Lect. https://doi.org/10.1002/9780470593042.ch5.

20. Ansley SJ, Badano JL, Blacque OE, Hill J, Hoskins BE, Leitch CC, Kim JC, Ross AJ, Eichers ER, Teslovich TM, Mah AK, Johnsen RC, Cavender JC, Lewis RA, Leroux MR, Beales PL, Katsanis N. Basal body dysfunction is a likely cause of pleiotropic Bardet-Biedl syndrome. Nature. 2003;425(6958):628-33. https:// doi.org/10.1038/nature02030.

21. Ferrante MI, Zullo A, Barra A, Bimonte S, Messaddeq N, Studer M, Dollé P, Franco B. Oral-facial-digital type I protein is required for primary cilia formation and left-right axis specification. Nat Genet. 2006;38(1):112-7. https://doi.org/10.1038/ng1684.

22. Ruiz-Perez VL, Blair HJ, Rodriguez-Andres ME, Blanco MJ, Wilson A, Liu YN, Miles C, Peters H, Goodship JA. Evc is a positive mediator of Ihh-regulated bone growth that localises at the base of chondrocyte cilia. Development. 2007;134(16):2903-12. https://doi.org/10.1242/dev.007542.

23. Digilio MC, Pugnaloni F, De Luca A, Calcagni G, Baban A, Dentici ML, Versacci P, Dallapiccola B, Tartaglia M, Marino B. Atrioventricular canal defect and genetic syndromes: the unifying role of sonic hedgehog. Clin Genet. 2019;95(2):268-76. https://doi.org/10.1111/cge.13375.

24. De Biase L, Di Ciommo V, Ballerini L, Bevilacqua M, Marcelletti C, Marino B. Prevalence of left-sided obstructive lesions in patients with atrioventricular canal without Down's syndrome. J Thorac Cardiovasc Surg. 1986;91(3):467-9.

25. Marino B. Congenital heart disease in patients with Down's syndrome: anatomic and genetic aspects. Biomed Pharmacother. 1993;47(5):197-200. https://doi.org/10.1016/0753-3322(93)90056-q.

26. Nguyen $\mathrm{HH}$, Jay PY. A single misstep in cardiac development explains the co-occurrence of tetralogy of fallot and complete atrioventricular septal defect in Down syndrome. J Pediatr. 2014;165(1):194-6. https://doi.org/10. 1016/j.jpeds.2014.02.065.

27. Marino B, Vairo U, Corno A, Nava S, Guccione P, Calabrò R, Marcelletti C. Atrioventricular canal in Down syndrome. Prevalence of associated cardiac malformations compared with patients without Down syndrome. Am J Dis Child. 1990;144(10):1120-2. https://doi.org/10.1001/archpedi.1990. 02150340066025.

28. Formigari R, Di Donato RM, Gargiulo G, Di Carlo D, Feltri C, Picchio FM, Marino B. Better surgical prognosis for patients with complete atrioventricular septal defect and Down's syndrome. Ann Thorac Surg. 2004; 78(2):666-72; discussion 672. https://doi.org/10.1016/j.athoracsur.2003.12.021.

29. Giamberti A, Marino B, Di Carlo D, lorio FS, Formigari R, De Zorzi A. Partial atrioventricular canal with congestive heart failure in the first year of life: surgical options. Ann Thor Surg. 1996;62(1):151-4. https://doi.org/10.1016/ 0003-4975(96)00262-7.

30. Jongewaard IN, Lauer RM, Behrendt DA, Patil S, Klewer SE. Beta 1 integrin activation mediates adhesive differences between trisomy 21 and nontrisomic fibroblasts on type VI collagen. Am J Med Genet. 2002;109(4):298305. https://doi.org/10.1002/ajmg.10413.

31. Arron JR, Winslow MM, Polleri A, Chang C-P, Wu H, Gao X, Neilson JR, Chen L, Heit JJ, Kim SK, Yamasaki N, Miyakawa T, Francke U, Graef IA, Crabtree GR. NFAT dysregulation by increased dosage of DSCR1 and DYRK1A on chromosome 21. Nature. 2006:441(7093):595-600. https://doi.org/10.1038/ nature04678. 
32. Ackerman C, Locke AE, Feingold E, Reshey B, Espana K, Thusberg J, Mooney S, Bean LJH, Dooley KJ, Cua CL, Reeves RH, Sherman SL, Maslen CL. An excess of deleterious variants in VEGF-A pathway genes in down-syndromeassociated atrioventricular septal defects. Am J Hum Genet. 2012;91(4):64659. https://doi.org/10.1016/j.ajhg.2012.08.017.

33. Li H, Cherry S, Klinedinst D, DeLeon V, Redig J, Reshey B, Chin MT, Sherman $\mathrm{SL}$, Maslen $\mathrm{CL}$, Reeves $\mathrm{RH}$. Genetic modifiers predisposing to congenital heart disease in the sensitized Down syndrome population. Circ Cardiovasc Genet. 2012;5(3):301-8. https://doi.org/10.1161/CIRCGENETICS.111.960872.

34. Fuchs C, Ciani E, Guidi S, Trazzi S, Bartesaghi R. Early-occurring proliferation defects in peripheral tissues of the Ts65Dn mouse model of Down syndrome are associated with patched1 over expression. Lab Investig. 2012; 92(11):1648-60. https://doi.org/10.1038/labinvest.2012.117.

35. Digilio MC, Marino B, Guccione P, Giannotti A, Mingarelli R, Dallapiccola B. Deletion 8p syndrome. Am J Med Genet. 1998;75(5):534-6. https://doi.org/ 10.1002/(SICI) 1096-8628(19980217)75:5<534::AID-AJMG15>3.0.CO;2-L.

36. Digilio MC, Giannotti A, Marino B, Dallapiccola B. Atrioventricular canal and 8p- syndrome. Am J Med Genet. 1993;47(3):437-8. https://doi.org/10.1002/ ajmg.1320470331.

37. Devriendt K, Matthijs G, Van Dael R, Gewillig M, Eyskens B, Hjalgrim H, Dolmer B, McGaughran J, Bröndum-Nielsen K, Marynen P, Fryns JP, Vermeesch JR. Delineation of the critical deletion region for congenital heart defects, on chromosome 8p23.1. Am J Hum Genet. 1999;64(4):1119_ 26. https://doi.org/10.1086/302330.

38. Pehlivan T, Pober BR, Brueckner M, Garrett $S$, Slaugh R, Van Rheeden R, Wilson DB, Watson MS, Hing AV. GATA4 haploinsufficiency in patients with interstitial deletion of chromosome region 8p23.1 and congenital heart disease. Am J Med Genet. 1999;83(3):201-6. https://doi.org/10.1002/ (SICI)1096-8628(19990319)83:3<201::AID-AJMG11>3.0.CO;2-V.

39. Zhou L, Liu J, Xiang M, Olson P, Guzzetta A, Zhang K, Moskowitz IP, Xie L. Gata4 potentiates second heart field proliferation and hedgehog signaling for cardiac septation. Proc Natl Acad Sci U S A. 2017;114(8):E1422-31. https://doi.org/10.1073/pnas.1605137114.

40. Phipps ME, Latif F, Prowse A, Payne SJ, Dietz-Band J, Leversha M, Affara NA, Moore AT, Tolmie J, Schinzel A. Molecular genetic analysis of the $3 p-$ syndrome. Hum Mol Genet. 1994;3(6):903-8. https://doi.org/10.1093/hmg/3. 6.903

41. Drumheller T, McGillivray BC, Behrner D, MacLeod P, McFadden DE, Roberson J, Venditti C, Chorney K, Chorney M, Smith DI. Precise localisation of 3p25 breakpoints in four patients with the 3p-syndrome. J Med Genet. 1996;33(10):842-7. https://doi.org/10.1136/jmg.33.10.842.

42. Green EK, Priestley MD, Waters J, Maliszewska C, Latif F, Maher ER. Detailed mapping of a congenital heart disease gene in chromosome 3p25. J Med Genet. 2000;37(8):581-7. https://doi.org/10.1136/jmg.37.8.581.

43. Rupp PA, Fouad GT, Egelston CA, Reifsteck CA, Olson SB, Knosp WM, Glanville RW, Thornburg KL, Robinson SW, Maslen CL. Identification, genomic organization and mRNA expression of CRELD1, the founding member of a unique family of matricellular proteins. Gene. 2002;293(1-2): 47-57. https://doi.org/10.1016/s0378-1119(02)00696-0.

44. Robinson SW, Morris CD, Goldmuntz E, Reller MD, Jones M, Steiner RD, Maslen CL. Missense mutations in CRELD1 are associated with cardiac atrioventricular septal defects. Am J Med Hum Genet. 2003;72(4):1047-52. https://doi.org/10.1086/374319.

45. Burnicka-Turek O, Steimle JD, Huang W, Felker L, Kamp A, Kweon J, Peterson M, Reeves RH, Maslen CL, Gruber PJ, Yang XH, Shendure J, Moskowitz IP. Cilia gene mutations cause atrioventricular septal defects by multiple mechanisms. Hum Mol Genet. 2016;25(14):3011-28. https://doi.org/10.1093/ $\mathrm{hmg} / \mathrm{ddw} 155$.

46. Chiang $C$, Litingtung $Y$, Lee E, Young KE, Corden $J$, Westphal H, Beachy PA. Cyclopia and defective axial patterning in mice lacking sonic hedgehog gene function. Nature. 1996;383(6599):407-13. https://doi.org/10.1038/ $383407 \mathrm{a} 0$

47. Meyers EN, Martin GR. Differences in left-right axis pathways in mouse and chick: functions of FGF8 and SHH. Science. 1999:285(5426):403-6. https:// doi.org/10.1126/science.285.5426.403.

48. Tsukui T, Capdevila J, Tamura K, Ruiz-Lozano P, Rodriguez-Esteban C, YoneiTamura S, Magallón J, Chandraratna RA, Chien K, Blumberg B, Evans RM, Belmonte JC. Multiple left-right asymmetry defects in Shh(-/-) mutant mice unveil a convergence of the shh and retinoic acid pathways in the control of Lefty-1. Proc Natl Acad Sci U S A. 1999;96(20):11376-81. https://doi.org/ 10.1073/pnas.96.20.11376.
49. Thomas $S$, Legendre $M$, Saunier $S$, Bessières B, Alby $C$, Bonnière $M$, Toutain A, Loeuillet L, Szymanska K, Jossic F, Gaillard D, Yacoubi MT, Mougou-Zerelli S, David A, Barthez M-A, Ville Y, Bole-Feysot C, Nitschke P, Lyonnet S, Munnich A, Johnson CA, Encha-Razavi F, Cormier-Daire V, Thauvin-Robinet C, Vekemans M, Attié-Bitach T. TCTN3 mutations cause Mohr-Majewski syndrome. Am J Hum Genet. 2012;91(2):372-8. https://doi.org/10.1016/j.ajhg. 2012.06.017.

50. Digilio MC, Dallapiccola B, Marino B. Atrioventricular canal defect in BardetBiedl syndrome: clinical evidence supporting the link between atrioventricular canal defect and polydactyly syndromes with ciliary dysfunction. Genet Med. 2006;8(8):536. https://doi.org/10.1097/01.gim. 0000232482.21714 .86 .

51. Valente EM, Logan CV, Mougou-Zerelli S, Lee JH, Silhavy JL, Brancati F, lannicelli M, Travaglini L, Romani S, Illi B, Adams M, Szymanska K, Mazzotta A, Lee JE, Tolentino JC, Swistun D, Salpietro CD, Fede C, Gabriel S, Russ C, Cibulskis K, Sougnez C, Hildebrandt F, Otto EA, Held S, Diplas BH, Davis EE, Mikula M, Strom CM, Ben-Zeev B, Lev D, Sagie TL, Michelson M, Yaron Y, Krause A, Boltshauser E, Elkhartoufi N, Roume J, Shalev S, Munnich A, Saunier S, Inglehearn C, Saad A, Alkindy A, Thomas S, Vekemans M, Dallapiccola B, Katsanis N, Johnson CA. Attié-Bitach ,T.; Gleeson, J.G. Mutations in TMEM216 perturb ciliogenesis and cause Joubert.; Meckel and related syndromes. Nat Genet. 2010;42(7):619-25. https://doi.org/10.1038/ng. 594.

52. Digilio MC, Marino B, Ammirati A, Borzaga U, Giannotti A, Dallapiccola B. Cardiac malformations in patients with oral-facial-skeletal syndromes: clinical similarities with heterotaxia. Am J Med Genet. 1999;84(4):350-6. https://doi. org/10.1002/(SICI)1096-8628(19990604)84:4<350::AID-AJMG8>3.0.CO;2-E.

53. Ruiz-Perez VL, Goodship JA. Ellis-van Creveld syndrome and Weyers acrodental dysostosis are caused by cilia-mediated diminished response to hedgehog ligands. Am J Med Genet C Semin Med Genet. 2009;151C(4): 341-51. https://doi.org/10.1002/ajmg.c.30226.

54. Digilio MC, Dallapiccola B, Marino B. Atrioventricular canal defect as a sign of laterality defect in Ellis-van creveld and polydactyly syndromes with ciliary and hedgehog signaling dysfunction. Pediatr Cardiol. 2012;33(5):8745. https://doi.org/10.1007/s00246-012-0270-3.

55. Peoples WM, Moller JH, Edwards JE. Polysplenia: a review of 146 cases. Ped Cardiol. 1983;4(2):129-37. https://doi.org/10.1007/BF02076338.

56. Kronenberg HM. Developmental regulation of the growth plate. Nature. 2003;423(6937):332. https://doi.org/10.1038/nature01657.

57. Caparrós-Martín JA, De Luca A, Cartault F, Aglan M, Temtamy S, Otaify GA, Mehrez M, Valencia M, Vázquez L, Alessandri J-L, Nevado J, Rueda-Arenas I, Heath KE, Digilio MC, Dallapiccola B, Goodship JA, Mill P, Lapunzina P, RuizPerez VL. Specific variants in WDR35 cause a distinctive form of Ellis-van Creveld syndrome by disrupting the recruitment of the EvC complex and SMO into the cilium. Hum Mol Genet. 2015;24(14):4126-37. https://doi.org/ 10.1093/hmg/ddv152.

58. Taylor SP, Dantas TJ, Duran I, Wu S, Lachman RS, Nelson SF, Cohn DH, Vallee RB, Krakow D. Mutations in DYNC2LI1 disrupt cilia function and cause short rib polydactyly syndrome. Nat Commun. 2015;6(1):1-11. https://doi.org/10. 1038/ncomms8092.

59. Niceta M, Margiotti K, Digilio MC, Guida V, Bruselles A, Pizzi S, Ferraris A, Memo L, Laforgia N, Dentici ML, Consoli F, Torrente I, Ruiz-Perez VL, Dallapiccola B, Marino B, De Luca A, Tartaglia M. Biallelic mutations in DYNC2LI1 are a rare cause of Ellis-van Creveld syndrome. Clin Genet. 2018; 93(3):632-9. https://doi.org/10.1111/cge.13128.

60. Gurrieri F, Franco B, Toriello H, Neri G. Oral-facial-digital syndromes: review and diagnostic guidelines. Am J Med Genet A. 2007;143(24):3314-23. https://doi.org/10.1002/ajmg.a.32032.

61. Digilio MC, Marino B, Giannotti A, Dallapiccola B. Orocardiodigital syndrome: an oral-facial-digital type II variant associated with atrioventricular canal. J Med Genet. 1996;33(5):416-8. https://doi.org/10.1136/jmg.33.5.416.

62. Gustavson K-H, Kreuger A, Petersson PO. Syndrome characterized by lingual malformation.; polydactyly.; tachypnea.; and psychomotor retardation (Mohr syndrome). Clin Genet. 1971;2(4):261-6. https://doi.org/10.1111/j.1399-0004. 1971.tb00287.x.

63. Su W-R, Wang P-H, Lian J-D, Lin MC-J. Oral-facial-digital syndrome with vaginal atresia, hydronephrosis and congenital cardiac defect. J Pediatr Orthop B. 2008;17(4):179-82. https://doi.org/10.1097/BPB.0b013e3282ff4f77.

64. Singla V, Romaguera-Ros M, Garcia-Verdugo JM, Reiter JF. Ofd1, a human disease gene.; regulates the length and distal structure of centrioles. Dev Cell. 2010;18(3):410-24. https://doi.org/10.1016/j.devcel.2009.12.022. 
65. Saari J, Lovell MA, Yu HC, Bellus GA. Compound heterozygosity for a frame shift mutation and a likely pathogenic sequence variant in the planar cell polarity-ciliogenesis gene WDPCP in a girl with polysyndactyly, coarctation of the aorta, and tongue hamartomas. Am J Med Genet A. 2015;167A(2): 421-7. https://doi.org/10.1002/ajmg.a.36852.

66. Karp N, Grosse-Wortmann L, Bowdin S. Severe aortic stenosis.; bicuspid aortic valve and atrial septal defect in a child with Joubert syndrome and related disorders (JSRD)-a case report and review of congenital heart defects reported in the human ciliopathies. Eur J Med Genet. 2012;55(11): 605-10. https://doi.org/10.1016/j.ejmg.2012.07.010.

67. Romani M, Micalizzi A, Valente EM. Joubert syndrome: congenital cerebellar ataxia with the molar tooth. Lancet Neurol. 2013;12(9):894-905. https://doi. org/10.1016/S1474-4422(13)70136-4.

68. Beales PL, Elcioglu N, Woolf AS, Parker D, Flinter FA. New criteria for improved diagnosis of Bardet-Biedl syndrome: results of a population survey. J Med Genet. 1999;36(6):437-46.

69. Slavotinek AM, Biesecker LG. Phenotypic overlap of McKusick-Kaufman syndrome with Bardet-Biedl syndrome: a literature review. Am J Med Genet. 2000;95(3):208-15. https://doi.org/10.1002/1096-8628(20001127)95:3<208:: AID-AJMG5>3.0.CO;2-J

70. Lorda-Sanchez I, Ayuso C, Ibañez A. Situs inversus and Hirschsprung disease: two uncommon manifestations in Bardet-Biedl syndrome. Am J Med Genet. 2000;90(1):80-1. https://doi.org/10.1002/(SICI)1096-8628(20000103)90:1<80:: AID-AJMG14>3.0.CO;2-E.

71. Kelley Rl, Hennekam RC. The smith-lemli-opitz syndrome. J Med Genet. 2000;37(5):321-35. https://doi.org/10.1136/jmg.37.5.321

72. Lin $A E$, Ardinger $H H$, Ardinger $\mathrm{RH}$, Cunniff C, Kelley Rl. Cardiovascular malformations in Smith-Lemli-Opitz syndrome. Am J Med Genet. 1997;68(3): 270-8. https://doi.org/10.1002/(SICI)1096-8628(19970131)68:3<270::AIDAJMG5>3.0.CO;2-Q.

73. Digilio MC, Marino B, Giannotti A, Dallapiccola B, Opitz JM. Specific congenital heart defects in RSH/Smith-Lemli-Opitz syndrome: postulated involvement of the sonic hedgehog pathway in syndromes with postaxial polydactyly or heterotaxia. Birth Defects Research Part A Clin Mol Teratol. 2003;67(3):149-53. https://doi.org/10.1002/bdra.10010.

74. Botto LD, Khoury MJ, Mastroiacovo P, Castilla EE, Moore CA, Skjaerven R, Mutchinick OM, Borman B, Cocchi G, Czeizel AE. The spectrum of congenital anomalies of the VATER association: an international study. Am J Med Genet. 1997;71(1):8-15. https://doi.org/10.1002/(SICI)1096-8628(19970711)71: $1<8:$. AID-AJMG2>3.0.CO;2-V.

75. Kim J, Kim P, Hui CC. The VACTERL association: lessons from the sonic hedgehog pathway. Clin Genet. 2001;59(5):306-15. https://doi.org/10.1034/j. 1399-0004.2001.590503.x.

76. Chung B, Shaffer LG, Keating S, Johnson J, Casey B, Chitayat D. From VACTERL-H to heterotaxy: variable expressivity of ZIC3-related disorders. Am J Med Genet A. 2011;155A(5):1123-8. https://doi.org/10.1002/ajmg.a.33859.

77. Hilger AC, Halbritter J, Pennimpede T, van der Ven A, Sarma G, Braun DA, Porath JD, Kohl S, Hwang D-Y, Dworschak GC, Hermann BG, Pavlova A, ElMaarri O, Nöthen MM, Ludwig M, Reutter H, Hildebrandt F. Targeted Resequencing of 29 candidate genes and mouse expression studies implicate ZIC3 and FOXF1 in human VATERNACTERL association. Hum Mutat. 2015;36:1150-4. https://doi.org/10.1002/humu.22859.

78. Friedland-Little JM, Hoffmann AD, Ocbina PJR, Peterson MA, Bosman JD, Chen Y, Cheng SY, Anderson KV, Moskowitz IP. A novel murine allele of intraflagellar transport protein 172 causes a syndrome including VACTERLlike features with hydrocephalus. Hum Mol Genet. 2011;20(19):3725-37. https://doi.org/10.1093/hmg/ddr241.

79. Laux D, Malan V, Bajolle F, Boudjemline Y, Amiel J, Bonnet D. FOX gene cluster defects in alveolar capillary dysplasia associated with congenital heart disease. Cardiol Young. 2013;23(5):697-704. https://doi.org/10.1017/ S1047951112001904.

80. Sen P, Yang Y, Navarro C, Silva I, Szafranski P, Kolodziejska KE, Dharmadhikari AV, Mostafa H, Kozakewich H, Kearney D. Novel FOXF1 mutations in sporadic and familial cases of alveolar capillary dysplasia with misaligned pulmonary veins imply a role for its DNA binding domain. Hum Mutat. 2013;34(6):801-11. https://doi.org/10.1002/humu.22313.

81. Tartaglia M, Zampino G, Gelb BD. Noonan syndrome: clinical aspects and molecular pathogenesis. Mol Syndromol. 2010;1(1):2-26. https://doi.org/10. 1159/000276766.

82. Aoki Y, Niihori T, Inoue S, Matsubara Y. Recent advances in RASopathies. J Hum Genet. 2016;61(1):33. https://doi.org/10.1038/jhg.2015.114.
83. Marino B, Digilio MC, Toscano A, Giannotti A, Dallapiccola B. Congenital heart diseases in children with Noonan syndrome: an expanded cardiac spectrum with high prevalence of atrioventricular canal. J Pediatr. 1999;4. https://doi.org/10.1016/s0022-3476(99)70088-0.

84. Digilio MC, Lepri FR, Dentici ML, Henderson A, Baban A, Roberti MC, Capolino R, Versacci P, Surace C, Angioni A, Tartaglia M, Marino B, Dallapiccola B. Atrioventricular canal defect in patients with RASopathies. Eur J Hum Genet. 2013;21(2):200-4. https://doi.org/10.1038/ejhg.2012.145.

85. Marino B, Gagliardi MG, Digilio MC, Polletta B, Grazioli S, Agostino D, Giannotti A, Dallapiccola B. Noonan syndrome: structural abnormalities of the mitral valve causing subaortic obstruction. Eur J Pediatr. 1995;154(12): 949-52. https://doi.org/10.1007/BF01958636.

86. Yang W, Wang J, Moore DC, Liang H, Dooner M, Wu Q, Terek R, Chen Q, Ehrlich MG, Quesenberry PJ, Neel BG. Ptpn11 deletion in a novel progenitor causes metachondromatosis by inducing hedgehog signalling. Nature. 2013;499(7459):491-5. https://doi.org/10.1038/nature12396.

87. Trip J, Van Stuijvenberg M, Dikkers FG, Pijnenburg MW. Unilateral CHARGE association. Eur J Pediatr. 2002;161(2):78-80. https://doi.org/10.1007/s00431001-0870-z.

88. Wyse RKH, Al-Mahdawi S, Burn J, Blake K. Congenital heart disease in CHARGE association. Pediatr Cardiol. 1993;14(2):75-81. https://doi.org/10. 1007/BF00796983.

89. Vergara P, Digilio MC, De Zorzi A, Di Carlo D, Capolino R, Rimini A, Pelegrini M, Calabro R, Marino B. Genetic heterogeneity and phenotypic anomalies in children with atrioventricular canal defect and tetralogy of Fallot. Clin Dysmorphol. 2006; 15(2):65-70. https:/doi.org/10.1097/01.mcd.0000198925.94082.ea.

90. Lalani SR, Safiullah AM, Fernbach SD, Harutyunyan KG, Thaller C, Peterson LE, McPherson JD, Gibbs RA, White LD, Hefner M, Davenport SLH, Graham JM, Bacino CA, Glass NL, Towbin JA, Craigen WJ, Neish SR, Lin AE, Belmont JW. Spectrum of CHD7 mutations in 110 individuals with CHARGE syndrome and genotype-phenotype correlation. Am J Hum Genet. 2006; 78(2):303-14. https://doi.org/10.1086/500273.

91. Solomon BD, Bear KA, Wyllie A, Keaton AA, Dubourg C, David V. Genotypic and phenotypic analysis of 396 individuals with mutations in sonic hedgehog. J Med Genet. 2012;49(7):473-9. https://doi.org/10.1136/ jmedgenet-2012-101008.

92. Belloni E, Muenke M, Roessler E, Traverse G, Siegel-Bartelt J, Frumkin A, Mitchell HF, Donis-Keller H, Helms C, Hing AV, Heng HHQ, Koop B, Martindale D, Rommens JM, Tsui L-C, Scherer SW. Identification of sonic hedgehog as a candidate gene responsible for holoprosencephaly. Nat Genet. 1996;14(3):353-6. https://doi.org/10.1038/ng1196-353.

93. Roessler E, Belloni E, Gaudenz K, Jay P, Berta P, Scherer SW, Tsui L-C, Muenke M. Mutations in the human sonic hedgehog gene cause holoprosencephaly. Nat Genet. 1996;14(3):357-60. https://doi.org/10.1038/ ng1196-357.

94. Roessler E, Du Y, Glinka A, Dutra A, Niehrs C, Muenke M. The genomic structure.; chromosome location.; and analysis of the human DKK1 head inducer gene as a candidate for holoprosencephaly. Cytogenet Cell Genet. 2000;89(3-4):220-4. https://doi.org/10.1159/000015618.

95. Roessler E. How a Hedgehog might see holoprosencephaly. Hum Mol Genet. 2003;12(90001):15R-25. https://doi.org/10.1093/hmg/ddg058.

96. Wallis DE, Roessler E, Hehr U, Nanni L, Wiltshire T, Richieri-Costa A, GillessenKaesbach G, Zackai EH, Rommens J, Muenke M. Mutations in the homeodomain of the human SIX3 gene cause holoprosencephaly. Nat Genet. 1999;22(2):196-8. https://doi.org/10.1038/9718.

97. Ming JE, Kaupas ME, Roessler E, Brunner HG, Golabi M, Tekin M, Stratton RF, Sujansky E, Bale SJ, Muenke M. Mutations in PATCHED-1, the receptor for SONIC HEDGEHOG, are associated with holoprosencephaly. Hum Genet. 2002;110(4):297-301. https://doi.org/10.1007/s00439-002-0695-5.

98. De La Cruz JM, Bamford RN, Roessler E, Muenke M. Potential role of NODAL and CRIPTO in holoprosencephaly. In: american journal of human genetics. Chicago: Univ Chicago Press; 2000. p. 385.

99. Gripp KW, Wotton D, Edwards MC, Roessler E, Ades L, Meinecke P, Richieri-Costa A, Zackai EH, Massagué J, Muenke M, Elledge SJ. Mutations in TGIF cause holoprosencephaly and link NODAL signalling to human neural axis determination. Nat Genet. 2000;25(2):205-8. https://doi.org/10.1038/76074.

100. Brown LY. Holoprosencephaly due to mutations in ZIC2: alanine tract expansion mutations may be caused by parental somatic recombination. Hum Mol Genet. 2001;10(8):791-6. https://doi.org/10. 1093/hmg/10.8.791 
101. Nanni L, Ming JE, Bocian M, Steinhaus K, Bianchi DW, De Die-Smulders C, Giannotti A, Imaizumi K, Jones KL, Del Campo M, Martin RA, Meinecke P, Pierpont MEM, Robin NH, Young ID, Roessler E, Muenke M. The mutational spectrum of the sonic hedgehog gene in holoprosencephaly: $\mathrm{SHH}$ mutations cause a significant proportion of autosomal dominant holoprosencephaly. Hum Mol Genet. 1999;8(13):2479-88. https://doi.org/10. 1093/hmg/8.13.2479

102. Marino B, Pueschel SM. Heart disease in persons with Down syndrome. Baltimore: Paul H Brookes Publishing; 1996.

103. Lo NS, Leung PM, Lau KC, Yeung CY. Congenital cardiovascular malformations in Chinese children with Down's syndrome. Chin Med J. 1989;102(5):382-6.

104. De Rubens Figueroa J, Del Pozzo Magaña B, Pablos Hach JL, Calderón Jiménez C, Castrejón Urbina R. Heart malformations in children with down syndrom. Rev Esp Cardiol. 2003;56(9):894-9. https://doi.org/10.1016/s03008932(03)76978-4.

105. Freeman SB, Bean LH, Allen EG, Tinker SW, Locke AE, Druschel C. Ethnicity, sex, and the incidence of congenital heart defects: a report from the National Down syndrome Project. Genet Med. 2008;10(3):173-80. https://doi. org/10.1097/GIM.0b013e3181634867.

106. Priest JR, Yang W, Reaven G, Knowles JW, Shaw GM. Maternal midpregnancy glucose levels and risk of congenital heart disease in offspring. JAMA Pediatr. 2015;169(12):1112-6. https://doi.org/10.1001/ jamapediatrics.2015.2831.

107. Mitchell LE, Agopian AJ, Bhalla A, Glessner JT, Kim CE, Swartz MD, Hakonarson H, Goldmuntz E. Genome-wide association study of maternal and inherited effects on left-sided cardiac malformations. Hum Mol Genet 2015;24(1):265-73. https://doi.org/10.1093/hmg/ddu420.

108. Maslen CL. Molecular genetics of atrioventricular septal defects. Curr Opin Cardiol. 2004;19(3):205. https://doi.org/10.1097/00001573-200405000-00003.

109. Guo Y, Shen J, Yuan L, Li F, Wang J, Sun K. Novel CRELD1 gene mutations in patients with atrioventricular septal defect. World J Pediatr. 2010;6(4):34852. https://doi.org/10.1007/s12519-010-0235-7.

110. Maslen CL, Babcock D, Robinson SW, Bean LJH, Dooley KJ, Willour VL, Sherman SL. CRELD1 mutations contribute to the occurrence of cardiac atrioventricular septal defects in Down syndrome. Am J Med Genet A. 2006: 140A(22):2501-5. https://doi.org/10.1002/ajmg.a.31494.

111. Asim A, Agarwal S, Panigrahi I, Sarangi AN, Muthuswamy S, Kapoor A. CRELD1 gene variants and atrioventricular septal defects in Down syndrome. Gene. 2018;641:180-5. https://doi.org/10.1016/j.gene.2017.10. 044.

112. Li H, Edie S, Klinedinst D, Jeong JS, Blackshaw S, Maslen $\mathrm{CL}$, Reeves $\mathrm{RH}$. Penetrance of congenital heart disease in a mouse model of Down syndrome depends on a trisomic potentiator of a disomic modifier. Genetics. 2016;203(2):763-70. https://doi.org/10.1534/genetics.116.188045.

113. Redig JK, Fouad GT, Babcock D, Reshey B, Feingold E, Reeves RH, Maslen CL. Allelic interaction between CRELD1 and VEGFA in the pathogenesis of cardiac Atrioventricular Septal defects. AIMS Genet. 2014;1(1):1-19. https:// doi.org/10.3934/genet.2014.1.1\#sthash.jksuJTeC.dpuf.

114. Ferese R, Bonetti M, Consoli F, Guida V, Sarkozy A, Lepri FR, Versacci P, Gambardella S, Calcagni G, Margiotti K, Piceci Sparascio F, Hozhabri H, Mazza T, Digilio MC, Dallapiccola B, Tartaglia M, Marino B, Hertog J, De Luca A. Heterozygous missense mutations in NFATC1 are associated with atrioventricular septal defect. Hum Mutat. 2018;39(10):1428-41. https://doi. org/10.1002/humu.23593.

115. Wilson L, Curtis A, Korenberg JR, Schipper RD, Allan L, Chenevix-Trench G, Stephenson A, Goodship J, Burn J. A large, dominant pedigree of atrioventricular septal defect (AVSD): exclusion from the Down syndrome critical region on chromosome 21. Am J Hum Genet. 1993; 53(6):1262-8

116. Cousineau AJ, Lauer RM, Pierpont ME, Burns TL, Ardinger RH, Patil SR, Sheffield VC. Linkage analysis of autosomal dominant atrioventricular canal defects: exclusion of chromosome 21. Hum Genet. 1994;93(2):103-8. https:// doi.org/10.1007/BF00210591

117. Weismann CG, Hager A, Kaemmerer H, Maslen CL, Morris CD, Schranz D, Kreuder J. Gelb, B.D.PTPN11 mutations play a minor role in isolated congenital heart disease. Am J Med Genet. 2005;136:146-51. https://doi.org/ 10.1002/ajmg.a.30789.

118. D’Alessandro LCA, Al Turki S, Manickaraj AK, Manase D, Mulder BJM, Bergin L, Rosenberg HC, Mondal T, Gordon E, Lougheed J, Smythe J, Devriendt K, Bhattacharya S, Watkins H, Bentham J, Bowdin S, Hurles
ME, Mital S. Exome sequencing identifies rare variants in multiple genes in atrioventricular septal defect. Genet Med. 2016;18(2):189-98. https:// doi.org/10.1038/gim.2015.60.

119. Al Turki S, Manickaraj AK, Mercer CL, Gerety SS, Hitz MP, Lindsay S, D'Alessandro LCA, Jawahar Swaminathan G, Bentham J, Arndt AK, Low J, Breckpot J, Gewillig M, Thienpont B, Abdul-Khaliq H, Harnack C, Hoff K, Kramer HH, Schubert S, Siebert R, Toka O, Cosgrove C, Watkins H, Lucassen AM, O'Kelly IM, Salmon AP, Bu'Lock F, Granados-Riveron J, Setchfield K, Thornborough C, Brook JD, Mulder B, Klaassen S, Bhattacharya S, Devriendt K, Fitzpatrick DF, Wilson DI, Mital S, Hurles ME. Rare variants in NR2F2 cause congenital heart defects in humans. Am J Hum Genet. 2014;94(4):574-85. https://doi.org/10.1016/j.ajhg.2014. 03.007.

120. Lin FJ, You LR, Yu CT, Hsu WH, Tsai MJ, Tsai SY. Endocardial cushion morphogenesis and coronary vessel development require chicken ovalbumin upstream promoter-transcription factor II. Arterioscler Thromb Vasc Biol. 2012;32(11):135-46. https://doi.org/10.1161/ATVBAHA. 112.300255

121. Priest JR, Osoegawa K, Mohammed N, Nanda V, Kundu R, Schultz K, Lammer EJ, Girirajan S, Scheetz T, Waggott D, Haddad F, Reddy S, Bernstein D, Burns T, Steimle JD, Yang XH, Moskowitz IP, Hurles M, Lifton RP, Nickerson D, Bamshad M, Eichler EE, Mital S, Sheffield V, Quertermous T, Gelb BD, Portman M, Ashley EA. De Novo and Rare Variants at Multiple Loci Support the Oligogenic Origins of Atrioventricular Septal Heart Defects. PLoS Genetics. 2016;12(4):1-25. https://doi.org/10.1371/journal.pgen.1005963.

122. Priest JR, Girirajan S, Vu TH, Olson A, Eichler EE, Portman M. Rare copy number variants in isolated sporadic and syndromic atrioventricular septal defects. Am J Med Genet A. 2012;158 A(6):1279-84. https://doi.org/10.1002/ ajmg.a.35315.

123. Digilio MC, Marino B, Cicini MP, Giannotti A, Formigari R, Dallapiccola B. Risk of congenital heart defects in relatives of patients with atrioventricular canal. Am J Dis Child. 1993;147(12):1295-7. https://doi.org/10.1001/archpedi. 1993.02160360037013

124. Nora JJ, Berg K, Nora AH. Cardiovascular diseases: genetics, epidemiology, and prevention. USA: Oxford University Press; 1991.

125. Brodwall K, Greve G, Leirgul E, Tell GS, Vollset SE, Øyen N. Recurrence of congenital heart defects among siblings-a nationwide study. Am J Med Genet A. 2017;173(6):1575-85. https://doi.org/10.1002/ajmg.a. 38237.

126. Yokouchi-Konishi T, Yoshimatsu J, Sawada M, Shionoiri T, Nakanishi A, Horiuchi C. Recurrent congenital heart diseases among neonates born to mothers with congenital heart diseases. Pediatr Cardiol. 2019;40(4):865-70. https://doi.org/10.1007/s00246-019-02083-6.

127. Gennarelli M, Novelli G, Digilio MC, Giannotti A, Marino B, Dallapiccola B. Exclusion of linkage with chromosome 21 in families with recurrence of non-Down's atrioventricular canal. Hum Genet. 1994;94(6):708-10. https:// doi.org/10.1007/bf00206969.

128. Robinson SW, Morris CD, Goldmuntz E, Reller D, Jones M, Steiner RD. Missense mutations in CRELD1 are associated with cardiac atrioventricular septal defects. Am J Hum Genet. 2003;72(4):1047-52. https://doi.org/10. 1086/374319

129. Zatyka M, Priestley M, Ladusans EJ, Fryer AE, Mason J, Latif F. Analysis of CRELD1 as a candidate 3p25 atrioventricular septal defect locus (AVSD2). Clin Genet. 2005;67(6):526-8. https://doi.org/10.1111/j.13990004.2005.00435.x.

130. Garg V, Kathiriya IS, Barnes R, Schluterman MK, King IN, Butler C. GATA4 mutations cause human congenital heart defects and reveal an interaction with TBX5. Nature. 2003;424(6947):443-7. https://doi.org/10.1038/ nature01827.

131. Sheffield VC, Pierpont ME, Nishimura D, Beck JS, Burns TL, Berg MA. Identification of a complex congenital heart defect susceptibility locus by using DNA pooling and shared segment analysis. Hum Mol Genet. 1997; 6(1):117-21. https://doi.org/10.1093/hmg/6.1.117.

132. Demal TJ, Heise M, Reiz B, Dogra D, Brænne I, Reichenspurner H, Männer J, Aherrahrou Z, Schunkert H, Erdmann J, Abdelilah-Seyfried S. A familial congenital heart disease with a possible multigenic origin involving a mutation in BMPR1A. Sci Rep. 2019;9(1):1-12. https://doi.org/10.1038/ s41598-019-39648-7.

133. Qian L, Mohapatra B, Akasaka T, Liu J, Ocorr K, Towbin JA, Bodmer R. Transcription factor neuromancer/TBX20 is required for cardiac function in 
Drosophila with implications for human heart disease. Proc Natl Acad Sci U

S A. 2008;105(50):19833-8. https://doi.org/10.1073/pnas.0808705105.

134. Opitz JM, Neri G. Historical perspective on developmental concepts and

terminology. Am J Med Genet A. 2013;161A(11):2711-25. https://doi.org/10. 1002/ajmg.a.36244.

135. Opitz JM. Phenotypes, pleiotropy, and phylogeny. Am J Med Genet C. 2017; 175(3):329-40. https://doi.org/10.1002/ajmg.c.31574.

\section{Publisher's Note}

Springer Nature remains neutral with regard to jurisdictional claims in published maps and institutional affiliations.

Ready to submit your research? Choose BMC and benefit from:

- fast, convenient online submission

- thorough peer review by experienced researchers in your field

- rapid publication on acceptance

- support for research data, including large and complex data types

- gold Open Access which fosters wider collaboration and increased citations

- maximum visibility for your research: over $100 \mathrm{M}$ website views per year

At $\mathrm{BMC}$, research is always in progress.

Learn more biomedcentral.com/submissions 